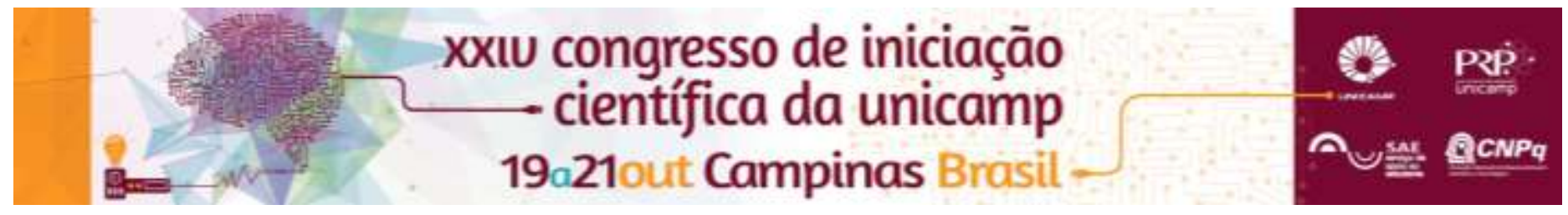

\title{
A cábula de aula como prática de liberdade e Zona Autônoma Temporária
}

\author{
Danilo M. Piaia*
}

\begin{abstract}
Resumo
A partir de um estudo conceitual teórico, buscou-se investigar a prática da cábula de aula - hoje conhecida entre os jovens como "matar aula" -, frequente entre alunos do Ensino Médio da rede pública, desde uma perspectiva ética distinta daquela que as instituições escolares e a sociedade de uma maneira geral costumam adotar.
\end{abstract}

\section{Palavras-chave:}

Cábula, liberdade, autonomia.

\section{Introdução}

A partir da noção de "práticas de liberdade", de Michel Foucault, é possível ressaltar e analisar o caráter produtivo da prática da cábula de aula no que toca à constituição do sujeito que a protagoniza. Ao mesmo tempo, em certa medida, é possível verificar que tal prática assume algumas características típicas da "Zona Autônoma Temporária" de Hakim Bey.

\section{Resultados e Discussão}

A metodologia da pesquisa consistiu basicamente no estudo teórico dos autores e conceitos mencionados acima, para em seguida desenvolver-se a estrutura das entrevistas que, em seguida, foram aplicadas com estudantes do Ensino Médio da rede pública da cidade de Campinas-SP.

A partir do estudo do principal texto do filósofo americano conhecido pelo pseudônimo Hakim Bey ${ }^{1}$, pode-se notar que a Zona Autônoma Temporária, ainda que não seja definida de maneira estrita pelo autor, tratase não de um espaço físico, mas de uma espécie de vivência ou experiência de autonomia social, cujo princípio motivador é o desejo que tem lugar dentro da margem de erro da vigilância estatal e social. Seu surgimento está relacionado ao aspecto de bando, que se refere à constituição da ZAT a partir de um grupo aberto, não pertencente a uma hierarquia maior e se constituindo e se organizando de forma horizontal; de festival, que se refere à espontaneidade e à festividade; e ao de nomadismo psíquico, possibilidade contemporânea de que as pessoas cultivem em si mesmas um lado desgarrado e desleal à concepção típica da sociedade ocidental a respeito da vida.

As ideias de Bey foram alvo de várias críticas, dentre as quais a principal é a de Murray Bookchin², que desde um ponto de vista ortodoxo acusa o desserviço que a ideia de Zona Autônoma Temporária teria prestado ao ideal de transformação social pela via revolucionária, dado seus supostos egocentrismo e fugacidade.

Partindo dos estudos de Foucault acerca da subjetivação dos indivíduos ${ }^{3}$, pode-se compreender como a liberação em relação à vigilância institucional e moral pode proporcionar aos indivíduos um espaço psíquico, um momento, que permite o desenvolvimento de uma subjetividade que difere daquela que é subjetivada por meio das tecnologias governamentais que têm o corpo dos indivíduos como objeto - por exemplo, aquelas aplicadas no interior do espaço escolar. A "experiência de pico" da Zona Autônoma Temporária, ainda que não efetue transformações materiais, foge aos códigos morais afetando e ocasionando uma diferença na subjetividade dos indivíduos que a protagonizam.

Com base nos estudos teóricos mencionados, desenvolveu-se a estrutura da entrevista que foi aplicada a dois grupos de alunos que alegaram cabular aula com certa frequência. As questões procuraram sondar de que maneira aconteciam estas experiências, aquilo que, na visão de seus protagonistas, as motivava, o que eles haviam sentido naquele momento, se foram descobertos e se houve punição, o que pensam hoje a respeito da prática etc.

\section{Conclusão}

Ainda que o curto tempo não tenha possibilitado entrevistar uma quantidade significativa de estudantes adeptos da prática, a partir da formação conceitual proposta, adotando uma perspectiva ética diferente daquela que costuma enquadrar estes jovens como maus alunos etc., abordou-se a questão de maneira a buscar respostas que apontassem para o "como" e o "porquê". Isto permitiu entrever como tal prática pode ser estudada enquanto uma rara experiência de autonomia em meio à rotina regrada destes jovens no interior das instituições escolares. Tais formulações poderiam, portanto, serem ponto de partida para um estudo mais aprofundado acerca dos efeitos subjetivos que estas experiências proporcionam aos que as protagonizam.

\section{Agradecimentos}

$\mathrm{O}$ apoio financeiro à Iniciação Científica se deu através do SAE/AF.

1 BEY, Hakim. TAZ: Zona Autônoma Temporária. 2. ed. São Paulo: Conrad Editora, 2004

2 BOOKCHIN, Murray. Anarquismo social o anarquismo personal: un abismo insuperable. Virus editorial: Barcelona, 2012

3 FOUCAUlT, M. 1984 - A Ética do Cuidado de Si como Prática da Liberdade. In: MOTTA, M. (org.) Ditos e Escritos V. 2 ed. Rio de Janeiro: Forense Universitária, 2006 